\title{
The Entry of Transition Countries of Central Europe in the European Union: Some Social Protection Issues*
}

\author{
VLADIMIR RYS ${ }^{* *}$ \\ University of Geneva, Switzerland
}

\begin{abstract}
After a brief survey of evidence showing that social security reform in each country of the region now follows its own path, the author reviews some general issues of social protection with special reference to transition countries. He then deals with several questions which preoccupy western observers in relation to EU enlargement: the emergence of a new model in addition to those already in place, the fear of social dumping and the interrogation regarding the possibility of keeping economic and social progress in equilibrium.

On the way to a successful enlargement, the respective protection levels should not create a problem in view of the relatively high standards maintained in this field in the past. The problem is rather on the EU side which finds it difficult to define with some precision the positive content of the European social model and the common goals. In view of their historical experience, the $\mathrm{CE}$ countries should be invited from the start to participate in the formulation of new European social policies.
\end{abstract}

Czech Sociological Review, 2000, Vol. 8 (No. 2: 131-138)

\section{Introduction}

The starting point of any meaningful discussion of this subject begins with the realisation that this particular enlargement of the European Union concerns a group of countries whose historical experience in the field of social protection differs fundamentally from that of the EU members, and therefore requires a particular approach to most topics normally raised in this context. Moreover, the developments in recent years seem to indicate that each country in this group follows its own path with regard to social security reform; this will of course further complicate matters in so far that no standard approach will be applicable to individual candidates. We have reviewed elsewhere the historical development of social security in Central Europe and its 'return to reality' [cf. Rys 1995] after the early adventures. However, the last point concerning the recent diversification of trends is important enough to merit a brief comment.

\section{Latest Trends in Pensions and in Health Protection}

To illustrate the variety of patterns of social reform prevailing in post-communist societies, it may be useful to concentrate our attention on two main branches of social security i.e. pensions and health protection, in three candidate countries of Central Europe, namely the Czech Republic, Hungary and Poland. In reviewing the recent developments, which cannot be reproduced here in detail, we get the following overall picture of the situation.

\footnotetext{
*) This text is based on a paper presented at the Conference on Financing Social Protection in Europe, held in Helsinki on 22-23 November 1999.

${ }^{* *}$ ) Direct all correspondence to: Vladimir Rys, 18, Chemin des Gotettes, CH-1222 Vésenaz, Suisse, fax +4122 75210 12, e-mailvrys@bluewin.ch
} 


\section{Pensions}

General development in the three candidate countries clearly indicates the presence of a trend towards a gradual reduction of the basic pension scheme, mostly supplemented by mandatory fully-funded private pension funds. We may even note a certain radicalisation of the pension reform the more we advance in time. This is due no doubt to the growing urgency of finding a solution to the pension problem and also to the emergence of what are considered to be new pension insurance techniques (cf. the use of the Swedish technique of 'notional individual accounts' in the most recent Polish reform).

Starting from a common basis under the communist regime, represented by state budget financing supported by a $40-50 \%$ tax on payrolls of all enterprises, new social insurance schemes gradually introduced employers' and employees' contributions, the former generally assuming a significantly higher part of the cost. In a drive for reducing their economic burden, all countries have abandoned the old principle of satisfaction of social needs in favour of a reinforcement of the insurance principle.

However, different approaches exist within this general trend. Regarding the mandatory nature of funded complementary schemes, the Hungarians and the Poles have followed the recommendation of the World Bank while the Czechs seem to be refusing it for the time being. Their main argument in favour of keeping the second pillar voluntary refers to the underdeveloped state of banking institutions and financial markets of the country. To put it bluntly, the Czechs would gladly accept something like the Swiss model if only they could have at their disposal a comparable level of banking and insurance industry. In this context, they point to the difficulties currently experienced in the implementation of complementary retirement schemes in Hungary, Poland and even in Sweden. ${ }^{1}$

Regarding the total contribution rate, it remained unchanged in Hungary and Poland where the proportion of means diverted to the second pillar represents $25 \%$ and $20 \%$ respectively (and is considerably higher than the Swedish rate of 14\%). The Czech government, which still prefers to keep the second pillar voluntary, is aware of the pressing need for increasing financial resources of the country's basic scheme. However, its proposal to have the contribution rate raised by $2.4 \%$ has already been rejected twice by Parliament. Clearly, they will have to look elsewhere for a source of finance.

It is too early to judge whether the cautious Czech approach or the Hungarian and Polish initiatives will provide a more appropriate answer to the pension problem. The performance of the second tier schemes will depend not only on economic and labour market developments, but also and perhaps above all, on the reactions of people to the new concept of security in old age. There is no doubt that these will be determined both by the attitudes common to the post-communist world and by the specific situation in each of the countries concerned.

\footnotetext{
1) The Polish scheme was supposed to be launched in January 1999 but the starting date had to be postponed by four months. The information technology required to track the individual funds of contributors ran into difficulties even in Sweden, where the launching of the system had to be postponed until mid-2000. In Hungary the original plan to raise the single employee contribution to private pension schemes from $6 \%$ to $8 \%$ by the year 2000 had to be abandoned by the new government. 
Vladimir Rys: The Entry of Transition Countries of Central Europe in the European Union

\section{Medical Care}

The history of health care in the three countries under review provides yet another example of different ways of handling the same issue. Starting from a common platform, i.e. a national health service provided free of charge by the Communist State, each of them followed a specific path. Hungary was the first country to introduce medical care insurance with some precipitation, only to reform it several times in subsequent years. The Czech Republic started implementing its health insurance scheme as of January 1993 and still suffers from the effects of a period of uncontrolled privatisation of health establishments. From the beginning Poland adopted a cautious approach, considering it preferable to improve first the operations of the existing health services before privatising them. The long expected reform was implemented only in January 1999.

Further differences in the provision and finance of health care appear in examining the role of the state and the pattern of cost-sharing by insured persons. Many of the main issues in this field, such as cost containment, remuneration of the medical profession or the financial management of health care establishments will present similarities with the situation in other European countries. Nevertheless, it will be found on close examination that many important aspects of these problems are specific to Central Europe.

Due to the complexity of the transition process there are serious problems in the co-ordination of the whole sector. This can be well observed in the Czech case, which shows how the lack of a clear concept of the health reform, of a transparent decisionmaking mechanism, and of an appropriate division of responsibilities between the Ministry of Health and the General Health Insurance Fund may for a long time block any legislative advance.

More serious still is the in-built disequilibrium in the economics of health insurance reform, which stems from the very nature of the risk. The maintenance of health represents for every individual, and indeed for every society, such a high value that its economic aspect is easily considered secondary in relation to the objective. Consequently, the medical care standards achieved by the Western world are immediately adopted by the transition countries although, objectively, they may not have the means to afford them. This explains why a patient in Central Europe may obtain under his health insurance a medicament free of charge which is available to his Western colleague on a costsharing basis; the problem is that while a single tablet may represent the cost of a cup of coffee in Paris, it will represent the cost of a dinner in Prague. This also explains the nearly permanent agitation of the medical profession demanding higher salaries and the difficulties of economic management of health care centres. For the solution to these problems a specific approach is required in the context of post-communist countries, which may point to the creation of an independent authority able to arbitrate between the conflicting views of different social actors.

\section{Some General Issues of Social Protection with Special Reference to Central Europe}

As shown by the above survey, there are different approaches to social security reform depending on the risk and on the country concerned. Latest developments in Central Europe, as indeed those in the rest of the world, fail to provide us with any clear indication as to the possible superiority of one particular method of financing over another. In all cases, social protection expenditure represents a charge on the economy (this supportive function being a substantial part of its raison d'être) which has to be kept in balance 
with its countervalue. This includes the most vital benefit the economy derives from the existence of social protection, now referred to as social cohesion. It used to be known as social peace based on social justice; it would seem, however, that many people no longer understand the meaning of these terms. It could also be described as the absence of social upheavals which are, in the light of past experience, generally unfavourable to economic growth.

As to the level of social protection expenditure, i.e. the question of what represents a necessary, tolerable, or equilibrium-preserving charge on the economy, this is a matter of a political consensus of the population - indispensable under a democratic government. To use modern language: "There is simply no hard and fast rule applicable to all societies and all economies as to how much social protection expenditure is financially and economically sustainable. The limits of sustainability can only be tested politically." [Cichon and Hagemejer 1996]

Rather than the financial method itself or any particular level of contributions, it is the social context in which the institution functions and the way it is perceived by the population that is of primary importance. One hundred dollars received from social assistance is not the same as one hundred dollars obtained through tax deductions or in the form of a social insurance benefit as of right. The post-communist society will always be highly sensitive to any attempt to reintroduce charity as a principle of social redistribution, even if this may appear to be economically effective. Experience has shown that, even in difficult economic conditions, people are more willing to pay social insurance contributions than taxes, as long as they have confidence in the system.

By definition, all social reforms have as their basic reference the situation in the past. The Central European societies are no exception to this rule, but their present situation is more complex because nobody ever dared to make a thorough evaluation of the communist welfare state. No government wished to complicate its life by analysing in detail the financial operations behind the system of social guarantees of the previous regime nor, for that matter, by declaring publicly a programme for the dismantlement of the communist welfare state. Some also preferred to avoid the risk of admitting the need for retaining some elements of the past system on account of their social efficiency. The general double-talk consisted of condemning loudly the paternalistic nature of the communist social protection system while doing everything possible so as to continue to make it work.

This situation has been highly confusing for the population, which has partly accepted the reduction in social benefits as a price to pay for personal freedom, some simply exchanging the old communist dogma for a new belief in the supreme power of the market. But there are also those who for some reason are unable to use the new freedom for the improvement of their personal situation and who, faced with the spectre of mass unemployment and deprived of any new vision of the future of the society they live in, will continue to talk about and possibly also work for the return of the 'good old times'. It is in this context that the entry in the European Union should give these populations new perspectives and new hopes. 


\section{European Union and Social Protection in Central Europe}

\section{Fifth European Social Model?}

As we have seen, social protection structures in the post-communist countries of Central Europe are on the move. While the pressure of demographic, economic and social factors behind this process may be considered broadly comparable, national responses to it differ quite significantly. This means that there does not seem to be a fifth European social model (assuming we agree with the existence of the other four). Some common trends are noted in health care, but this does not add up to a special model. In the field of pensions, we are witnessing the application to Central Europe of a conventional approach to social protection in developing countries, advocated in the past few years by the World Bank. Apart from the error which consists in mixing the problems of developing and transition countries under the same heading, we may ask, in these times marked by the pursuit of sustainability, just how sustainable is this conceptual model?

A highly interesting paper was published recently [Orszag and Stiglitz 1999], coauthored by the Senior Vice-President and Chief Economist of the World Bank, suggesting that a privately managed defined-contribution system may not always be the best solution for a country and that the second pillar may well consider adopting a public defined-benefit plan. The statement is based on the recognition that a number of factors, including the quality of financial institutions in a country, may determine the outcome of any particular model.

Furthermore, the question of notional individual accounts, applied in Sweden and most recently in Poland, came under scrutiny in a recent issue of the International Social Security Review [Cichon 1999]. A leading ILO social security expert analyses the concept of notional defined-contribution schemes and comes to the conclusion that while this is certainly an ingenious policy instrument for making the reduction of pension levels more acceptable, most of its potential financial and distributive effects could also be achieved by a classical defined-benefit scheme. This finding seems to underline the predominance of the political factor in all recent reforms while reinforcing the invitation to a cautious approach to models.

\section{Social Dumping}

Coming to the question of social dumping, this is yet another term which has been borrowed from the social protection vocabulary of developing countries, without fitting well into the analysis of the situation in transition societies. One can hardly suspect responsible governments of artificially keeping down the social protection levels of their populations in order to better sell their products; such behaviour would be close to political suicide. But we could no doubt identify a number of external advisors guilty of inciting social dumping when trying to sell their personal or institutional convictions regarding a hypothetical need for a general reduction of social expenditure in the countries concerned.

This could possibly be the case of a statement which is to be attributed to the authors of the most recent World Bank report regarding EU accession of the Czech Republic ["Czech..." 1999: 11]. "As the country prepares to enter the EU, it is incumbent that its social protection system is in line with the other EU countries. Considerable effort has already been made in that direction. Nonetheless, it is equally important that the Czech Republic not be burdened by some of the problems inherent in the social protection systems of a number of EU countries, since these problems would be magnified in the Czech 
Republic, which lacks the income cushion to support overly expensive social entitlements." The usefulness of general statements such as this is questionable; it is also out of touch with the political reality of the country. Consequently, it cannot but reinforce the position of those who do not really favour a well balanced social and economic development.

The threats of social dumping which may come from the private sector can best be dealt with through appropriate government regulations, making it plain to everybody that transition societies are governed by democratically elected representatives of the population and not by private commercial interests, no matter how global they may be.

\section{Equilibrium between Economic and Social Progress}

Any well conceived social protection system must be based on a comprehensive approach to social risks and provide for a full co-ordination of all social measures within the framework of a global concept of social policy. The formulation of social policy objectives, which has to rely on a political consensus, will always imply some degree of redistribution of available resources. Nobody will seriously question the primordial role of governments in this process.

The situation is different when it comes to co-ordinating and fixing objectives in the economic sector. During this exercise, many will start invoking the imperatives of free trade and decrying any government interference with the so-called market forces. The experience has shown that in the long run this position is untenable. The first condition for obtaining equilibrium in social and economic matters is hence the recognition of the duty of governments to regulate not only social but also economic processes. At present, ordinary people in transition countries often find it difficult to see what the real centres of political power in their globalised universe are. The EU authorities stand hence a good chance of finding a receptive audience for most of their social norms, if only they can avoid playing into the hands of those who readily proclaim that "nothing has changed, only the instructions from Moscow have been replaced by those from Brussels".

With regard to the political consensus on which to base a national social policy, and ultimately any convergent moves at the European level, care should be taken to recognise the somewhat deficient nature of the underlying mechanism in transition countries: it is marked by a relatively low level of involvement of civil society in the formulation of social policy. This is due to the long history of perverse abuse of different organisations of civil society by the previous regime, from trade unions to associations for peace or friendship with this or that country. The long-term effects of this collective memory, and in some cases also the influence of recent government policies, have not yet been fully overcome.

In order to arrive at a social and economic equilibrium based on a political consensus supported by civil society, the terms of the deal should be readily understood with respect to both sides of the balance. Admittedly, it is relatively easier to work out economic targets and indicators; the purpose and objectives of social policy are more difficult to define. The consensus which formed the basis of the European welfare state in the post-war years suffered greatly under the attacks of neo-liberal ideology. The populations in transition countries, confused by the use of new and misleading terminology, have no means of falling back on past experience and separating the wheat from the chaff. It would hence seem highly important to go back to the roots of this creation, to reinvent social insurance in its relationship with other social protection measures, and to restate 136 
the ideas of the welfare state in a language adapted to present circumstances. Without a new concept of the welfare state and a new vision of society, any attempt to reach the desired equilibrium will remain a shadow-boxing act.

Lastly, let there be no mistake about it, the search for a social and economic equilibrium is inseparable from the search for an equilibrium between personal freedom and collective constraints; a combination of both is necessary to guarantee the security of individual human existence in society. This has a direct implication for the political system we wish to have. To sacrifice those at the bottom of society for the sake of the better comfort and higher performance of its stronger members is not the sign of a will to build a truly democratic system. It is rather a sign of a regression to our obscurantist past.

\section{What to Expect From Entry into the EU?}

It goes without saying that the impact is likely to be different from one country to another, depending on the present state of development of its social protection system. In general, judging from the Commission's regular reports on progress towards accession, with the exception of work safety and social dialogue, this field does not give rise to major preoccupations. After all, the social protection standards of the Communist welfare state were in many respects superior to those of Western Europe and not all of them have disappeared. The immediate consequences of the pre-entry requirements are therefore not likely to be very significant. The question which many people ask themselves is what impact will this step make on the future development of their schemes.

The simple citizen may experience in due time some negative influence regarding his present 'social comfort'. Comparative tables often present straightforward statistical figures while forgetting to add some highly important footnotes. Thus, for instance, it may not be generally known that income from pensions in most post-communist countries is not taxed. It is quite likely that this kind of arrangement will eventually be adapted to the majority standard within the Union. Similar instances will be found in the field of health care, especially in relation to disabled people. The populations of the countries concerned may not even be aware of a number of these 'residual advantages' which have become part of their everyday life.

But this type of adaptation process is not likely to become the essential issue. As we have already mentioned, what people in Central Europe expect most of the European Union is a new vision of the future, a new set of goals to work for. The first step towards this objective could be made by a renewed effort to give a positive definition to what is referred to as the European social model. It has been identified so far mainly as a concept indicative of what most people are against; time has perhaps come to try to give expression to what it stands for. This would imply the already suggested restatement of the principles of a modern welfare state, the identification of common values and the formulation of basic goals to be shared by all EU members. This could possibly be done along the lines which have been investigated recently by some research studies [Pieters and Nikless 1998].

How far could EU authorities go beyond the formulation of common goals is an open question. What the Central European countries can least afford is social experimentation with models which would not correspond to the realities of their societal environment. We have argued elsewhere [Rys 1999a, b] that it is the political aspect of social reforms which dominates the scene and even the potential impact of demographic and economic factors forming part of this environment is subject to an evaluation by social 
actors involved in the decision-making process. It would hence seem meaningful to give these countries the possibility to choose their own means towards the achievement of common objectives and not to try to impose on them any institutional constraints. This should not exclude the use of some normative guidance on condition that it would provide enough room for adaptation.

To the extent that a European social model can only be a dynamic concept capable of further expansion, it would also seem reasonable to associate from the start the new members in its development. As we pointed out at the beginning, these countries have a unique historical experience and, in view of the long break with their own past, a capacity to look at social protection problems with new eyes. The communist approach to the treatment of some fundamental social issues such as mass unemployment was an unqualified failure; in this respect, the present situation can in no way be interpreted as a success of the capitalist approach. The old problem is still there in all its complexity and a new global vision of a democratic society of the year 2000 is needed to pursue the search for more stable conditions of social advancement and economic growth.

VLADIMÍR RYS is a specialist in the sociology of social security which he studied at the London School of Economics (B.A. Hon.) and at the Sorbonne in Paris (PhD). After the beginning of an academic career at LSE, he joined the Secretariat of the International Social Security Association (ISSA) in Geneva and became Head of its Research and Documentation Service. He was later appointed Secretary General of ISSA (1975-1990). On termination of his mandate he returned to academic activities as researcher, lecturer and scientific collaborator of the Universities of Prague and Geneva.

\section{References}

Cichon, M., K. Hagemejer 1996. "Social Protection Expenditure: A Review of Macro-Economic Issues." Pp. 167-185 in Finding the Balance: Financing and Coverage of Social Protection in Europe. Geneva: ISSA.

Cichon, M. 1999. "Notional Defined-Contribution Schemes: Old Wine in New Bottles?" International Social Security Review 52: 87-105.

“Czech Republic: Toward EU Accession - Summary Report.” 1999. A World Bank Country Study, September 1999.

Orszag, P. R., J. E. Stiglitz 1999. "Rethinking Pension Reform: Ten Myths About Social Security Systems." Paper presented to the Conference on New Ideas About Old Age Security, The World Bank, September 1999.

Pieters, D., J. Nickless 1998. Pathways for Social Protection in Europe. Helsinki: Ministry of Social Affairs and Health.

Rys, V. 1995. "Social Security Developments in Central Europe: A Return to Reality." Czech Sociological Review 3: 197-208.

Rys, V. 1999a. La sécurité sociale dans une société en transition: l'expérience tchèque. Quels enseignements pour l'Europe? Lausanne: Réalités sociales.

Rys, V. 1999b. "The Role of Basic Factors of Societal Environment in the Czech Social Security Reform.” Paper presented to the annual meeting of RC 19 (International Sociological Association), Prague, September, 1999. 